\title{
Lupus nefritli bir olguda sistemik steroidlerin ender bir komplikasyonu: mediyastinal lipomatoz olgusu
}

\author{
Mediastinal lipomatosis: as a rare complication of systemic steroids in an \\ adolescent with lupus nephritis
}

Sayın Editör,

Mediyastinal lipomatoz (ML), mediyastende aşırı yağ birikimine bağlı ortaya çıkan ve ender görülen bir durumdur (1). Sıklıkla endojenik ya da iyatrojenik Cushing Sendromu ya da şişmanlık ile ilişkilidir $(2,3)$. Mediyastinal lipomatoz olguları, hiçbir klinik bulgu vermeyeceği gibi, aşırı yağ birikimine bağlı ortaya çıkan ve ciddi bası bulgularına neden olan klinik bulgularla da karşımıza çıkabilir. Ön-arka göğüs grafisinde görülen mediyastende iki taraflı genişleme en sık radyolojik bulgudur ve mediyastene ait kitleler ile karıştırılabilir (1). Kesin tanı, bilgisayarlı tomografi (BT) veya manyetik rezonans (MR) görüntüleme ile konur $(4,5)$. Steroide bağlı ML genellikle iyi seyirlidir ve steroid dozunun azaltılması ya da kesilmesi ile geriler. Buna karşılık ciddi bası bulgularına yol açan ve cerrahi girişim gerektiren olgular literatürde bildirilmiştir $(5,6)$. Biz de bu olgu nedeni ile sistemik steroid kullanımının ender görülen bu komplikasyonuna dikkat çekmek istedik.

Dört yıl önce sistemik lupus eritematozus (SLE) tanısı alan ve böbrek biyopsisi evre IV yaygın membranoproliferatif glomerülonefrit ile uyumlu olan 17 yaşında kız hasta, aktif hastalık nedeniyle çok sayıda damar yoluyla yüksek doz metilprednizolon, damar yolu ile siklofosfamid ve ağız yolu ile prednizolon ve azatiyoprin/mikofenalat mofetil (MMF) tedavileri almıştı. Poliklinik kontrolü için başvurduğunda $40 \mathrm{mg}$ prednizolon ve $1000 \mathrm{mg}$ MMF tedavileri almakta idi. Fizik bakıda genel durumu düşkün ve soluk görünümde idi. Ay-dede yüz görünümü, bufalo hörgücü, bacak sırtında ödemi vardı. Kan basıncı 150/100 mmHg, nabzı 86/dak, solunum sayısı 20/dak idi. Periferik lenfadenomegalisi ya da organomegalisi yoktu. Kalp muayenesinde mezokardiyak odakta 2/6 sistolik üfürüm duyulmakta idi, diğer sistem muayeneleri doğaldı. Laboratuvar tetkikleri değerlendirildiğinde derin anemi (hemoglobin: 6,5 g/dL, haptoglobin: $<28,5 \mathrm{mg} / \mathrm{dL}$ ), hipoalbüminemi (serum albümin: 2,6 g/dL), proteinüri (idrar protein: $2,1 \mathrm{~g} / \mathrm{gün}$ ) ve böbrek işlevinde bozukluk (serum kreatinin: 2,2 mg/dL) saptandı. Ön-arka göğüs grafisinde üst mediyastene ait iki taraflı genişleme dikkati çekti (Şekil 1). Ekokardiyografisinde perikardiyal efüzyon $(6 \mathrm{~mm})$ ve hipertansiyona ikincil sol ventrikül hipertrofi bulguları vardı. Mediyastene ait kitle şüphesi ile göğüs BT (kontrastsız) çekildi; üst mediyastende yaygın yağ tutulumu saptandı (Şekil 2).

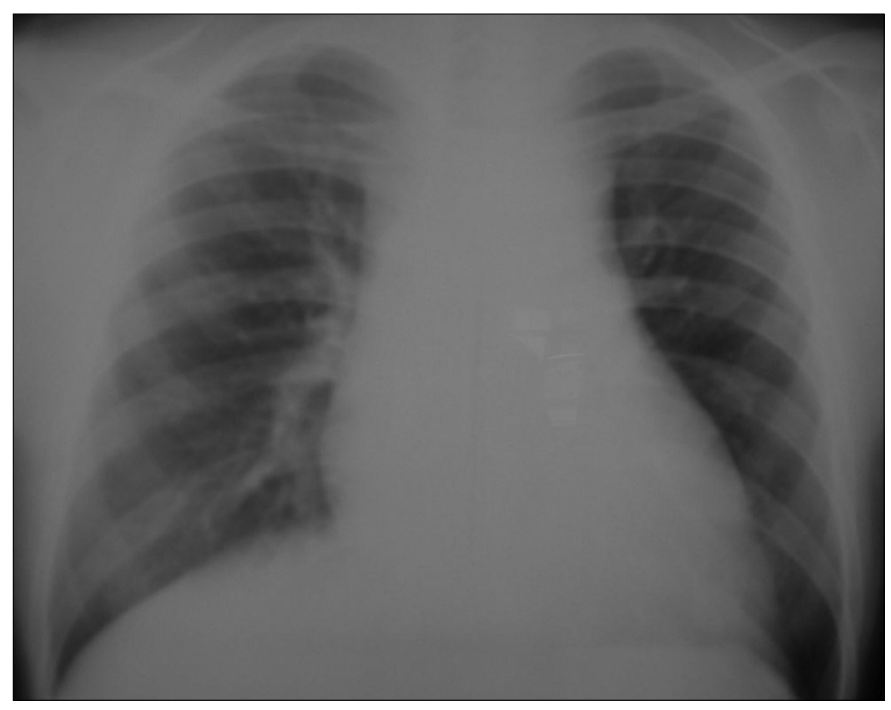

Şekil 1. Ön-arka göğüs grafisinde üst mediyastende iki taraflı düzgün sınırlı genişleme

Yazışma Adresi/Address for Correspondence: Dr. Nur Canpolat, İstanbul Üniversitesi Cerrahpaşa Tıp Fakültesi, Çocuk Nefroloji Bilim Dalı, İstanbul, Türkiye E-posta: ncanpolat2000@hotmail.com Geliş Tarihi/Received: 17.10.2012 Kabul Tarihi/Accepted: 24.10.2012

Türk Pediatri Arşivi Dergisi, Galenos Yayınevi tarafindan basılmıştrr. / Turkish Archives of Pediatrics, published by Galenos Publishing 


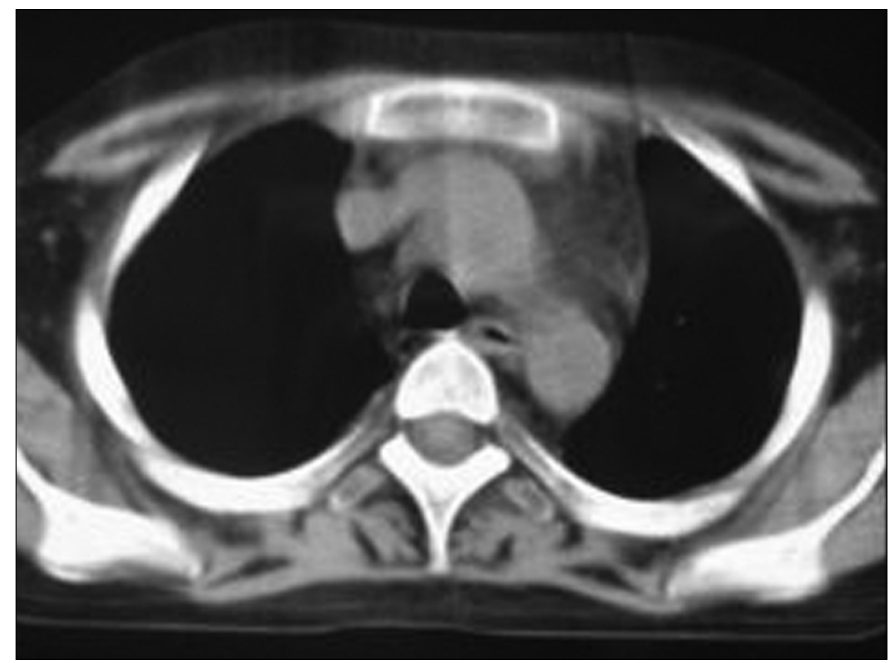

Şekil 2. Göğüs BT'de mediyastende yaygın yağ tutulumu

Mediyastene ait adenomegali ya da kitle görünümü yoktu. Uzun süre yüksek dozda steroid tedavisi kullanma öyküsü olan hastada steroide bağlı ML düşünüldü ve steroid dozu 10 mg'a kadar azaltıldı; ancak hastalığın çok aktif seyretmesi nedeni ile kesilemedi. Dört hafta sonraki kontrol grafisinde, mediyastendeki genişlemenin gerilediği gözlendi.

Mediyastinal lipomatoz, sistemik steroidlerin ender bir komplikasyonudur ve ilk kez 1966 yılında Koerner ve Sun (1) tarafından tanımlanmıştır. Bilgilerimize göre, bugüne kadar sadece bir çocuk olguda steroide bağlı ML bildirilmiştir (7). Hastaların bir kısmında hiçbir klinik bulgu yokken, bazı hastalarda hava yollarına, vena kava superiora, kalbe ve diğer organlara ait ciddi bası bulguları görülebilir (6,8-10). Bizim hastamızda ML'nin basısına bağlı olabileceği düşünülen herhangi bir klinik bulgu yoktu. Bununla birlikte, olgumuzun ekokardiyografik incelemesinde perikardiyal efüzyon vardı. Literatürdeki olgular değerlendirildiğinde, Hsu ve ark. (11) ML'ye bağlı bir perikardiyal efüzyon olgusu bildirmişlerdi. Ancak SLE tanısı ile izlenen ve hipoalbüminemisi olan bizim olgumuzda perikardiyal efüzyonu tek başına $\mathrm{ML}$ ile açıklamanın olası olmadığı kanısındayız.

Mediyastinal lipomatoz tanısı genellikle göğüs grafisinde mediyastinal genişlemenin gözlenmesi ve yağa ait yoğunluk değişikliğinin BT ya da MR görüntülemelerde gösterilmesi ile konur. Bu olguda da ilk olarak mediyasten genişlemesi fark edilmiş, uzun süreli ve yoğun bağışıklık sistemi baskılayıCı tedavi almış olması nedeni ile ikincil malinite olasılığı düşünülerek BT çekilmiş ve yaygın yağ kitlesinin BT'de gösterilmesi ile $\mathrm{ML}$ tanısı konmuştur. Uzun süreli steroid kullandığı bilinen ve steroide ait klinik bulgular (ay dede yüz görünümü ve bufalo hörgücü) gelişmiş olan olguda $\mathrm{ML}$ nedeninin steroide bağlı olduğu düşünülmüştür. Steroid tedavisinin azaltılması ile mediyastendeki genişlemenin gerilemesi tanımızı desteklemiştir.

Sonuç olarak ML, sistemik steroid kullanan ve mediyastinal genişlemesi olan hastalarda akılda bulundurulması ve ayırıcı tanıda düşünülmesi gereken ender bir komplikasyondur.

\section{Nur Canpolat, Sebuh Kuruğoğlu*, Lale Sever, Salim Çalışkan, Meltem Kıvılcım**, Özgür Kasapçopur***, Nil Arısoy*** Istanbul Üniversitesi Cerrahpaşa Tıp Fakültesi, Çocuk Nefroloji Bilim Dalı, Istanbul, Türkive *Istanbul Üniversitesi Cerrahpaşa Tıp Fakültesi, Radyoloji Anabilim Dalı, istanbul, Türkive \\ **istanbul Üniversitesi Cerrahpaşa Tıp Fakültesi, Çocuk Sağlığı ve Hastalıkları Anabilim Dall, Istanbul, Türkiye \\ ***Istanbul Üniversitesi Cerrahpaşa Tıp Fakültesi, Çocuk Romatoloji Bilim Dalı, Istanbul, Türkiye}

\section{Kaynaklar}

1. Koerner HJ, Sun DI. Mediastinal lipomatosis secondary to steroid therapy. Am J Roentgenol Radium Ther Nucl Med 1966; 98: 461-4.

2. Nguyen KQ, Hoeffel C, Le LH, Phan HT. Mediastinal lipomatosis. South Med J 1998; 91: 1169-72.

3. Lee WJ, Fattal G. Mediastinal lipomatosis in simple obesity. Chest 1976; 70: 308-9.

4. Enzi G, Biondetti PR, Fiore D, Mazzoleni F. Computed tomography of deep fat masses in multiple symmetrical lipomatosis. Radiology 1982; 144: $121-4$.

5. Nguyen KQ, Hoeffel C, Le LH, Phan HT. Mediastinal lipomatosis. South Med J 1998; 91: 1169-72.

6. Taille C, Fartoukh M, Houel R, Kobeiter H, Remy P, Lemaire F. Spontaneous hemomediastinum complicating steroid-induced mediastinal lipomatosis. Chest 2001; 120: 311-3.

7. Shukla LW, Katz JA, Wagner ML. Mediastinal lipomatosis: a complication of high dose steroid therapy in children. Pediatr Radiol 1988; 19: 57-8.

8. Sorhage F, Stover DE, Mortazavi A. Unusual etiology of cough in a woman with asthma. Chest 1996; 110: 852-4.

9. Gombar S, Mitra S, Thapa D, Gombar KK, Pathak R. Anesthetic considerations in steroid-induced mediastinal lipomatosis. Anesth Analg 2004; 98: 862-4.

10. Bulakci M, Yahyayev A, Ucar A, Erer B, Erer B, Dursun M. Unusual cause of right ventricular outflow tract compression: mediastinal lipomatosis. J Thorac Imaging 2011; 26: W134-6.

11. Hsu YM, Yao NS, Liu JM. Steroid-induced mediastinal lipomatosis with radiographic features of pericardial effusion. Am J Emerg Med 2000; 18: $346-8$. 